\title{
Grid-tied Power Conditioning System for Fuel Cell Composed of Three-phase Current-fed DC-DC Converter and PWM Inverter
}

\author{
Jong-Kyou Jeong*, Ji-Heon Lee*, Byung-Moon Han ${ }^{\dagger}$ and Han-Ju Cha**
}

\begin{abstract}
This paper proposes a grid-tied power conditioning system for fuel cell, which consists of three-phase current-fed DC-DC converter and three-phase PWM inverter. The three-phase current-fed DC-DC converter boosts fuel cell voltage of 26-48 V up to $400 \mathrm{~V}$ with zero-voltage switching (ZVS) scheme, while the three-phase PWM(Pulse Width Modulation) inverter controls the active and reactive power supplied to the grid. The operation of the proposed power conditioning system with fuel cell model is verified through simulations with PSCAD/EMTDC software. The feasibility of hardware implementation is verified through experimental works with a laboratory prototype with $1.2 \mathrm{~kW}$ proton exchange membrane (PEM) fuel cell stack. The proposed power conditioning system can be commercialized to interconnect the fuel cell with the power grid.
\end{abstract}

Keywords: Fuel cell power generation, Proton exchange membrane (PEM) fuel cell, Zero-voltage switching (ZVS), DC-DC converter with digital control

\section{Introduction}

Fuel cells, such as solar cell, are clean energy sources for electricity generation. Many types of fuel cell were developed for supplying electricity to cars or homes. Proton exchange membrane (PEM) fuel cell, which has a simple structure and high-power density, is considered as a DC power source for distributed power generation and passenger cars [1], [2].

Fuel cells have non-linear characteristic in electrical operation due to the polarization phenomena of electrochemical reaction. The terminal voltage at the rated load drops to the half value of the terminal voltage at no load. Thus, a highly efficient DC-DC converter is required to boost up the low terminal voltage to the high DC link voltage [3], [4].

Full-bridge, push-pull, and boost converters have been proposed as DC-DC converters for fuel cells. Full-bridge converter has a disadvantage of high switching loss due to the large number of switching units. Push-pull converter has lower switching loss due to lower number of switching units, but it has $88 \%$ efficiency because it still requires double-winding structure in the primary side. Boost converter has lower switching loss due to the small number of switching units, but it has lower voltage-boosting ratio of three to four times. Multi-stage boost converter without transformer was developed to obtain high voltage-boosting ratio; however, its efficiency is at the range of $86-90 \%$. Isolated boost converter was also developed to obtain high

\footnotetext{
$\dagger \quad$ Corresponding Author: Department of Electrical Engineering Myongji University, Yongin, Korea (erichan@mju.ac.kr)

* Department of Electrical Engineering Myongji University, Yongin, Korea (jjuk486@mju.ac.kr)

** Department of Electrical Engineering, Chungnam National University (hjcha@cnu.ac.kr)

Received: July 5, 2010; Accepted: October 11, 2010
}

voltage-boosting ratio, with efficiency of between $86 \%$ and $90 \%$. In order to increase the efficiency and to reduce the number of components, various type of converters were proposed by many researchers [5], [6], [7], [8].

Recently, three-phase power transfer concept has been extended to the DC-DC converter for high-power and highefficiency applications. One coauthor of this paper proposed a three-phase DC-DC converter with boost inductor, active clamp, three-phase delta-delta wound transformer, and three-phase diode rectifier. Its performance was verified through experimental work with variable DC source and resistive DC load [9], [10], [11], [12].

This paper describes the analysis results of the grid-tied power conditioning system for fuel cell, which is composed of three-phase DC-DC converter and three-phase PWM inverter. The performance of the proposed power conditioning system was verified by computer simulations with PSCAD/EMTDC. Furthermore, the feasibility of the hardware implementation was confirmed by experimental works with a prototype connected to $1.2 \mathrm{~kW}$ PEM fuel cell.

\section{Proposed Power Conditioning System}

Fig. 1 shows the configuration of the proposed power conditioning system for fuel cell, including the whole system controller.

The power conditioning system requires high boost ratio DC-DC converter to compensate the severe output voltage variation of the fuel cell between the no-load and full-load conditions. The DC-DC converter introduced in this study operates in zero-voltage switching (ZVS) by using the active clamp to improve efficiency.

The whole system controller is divided into the control 


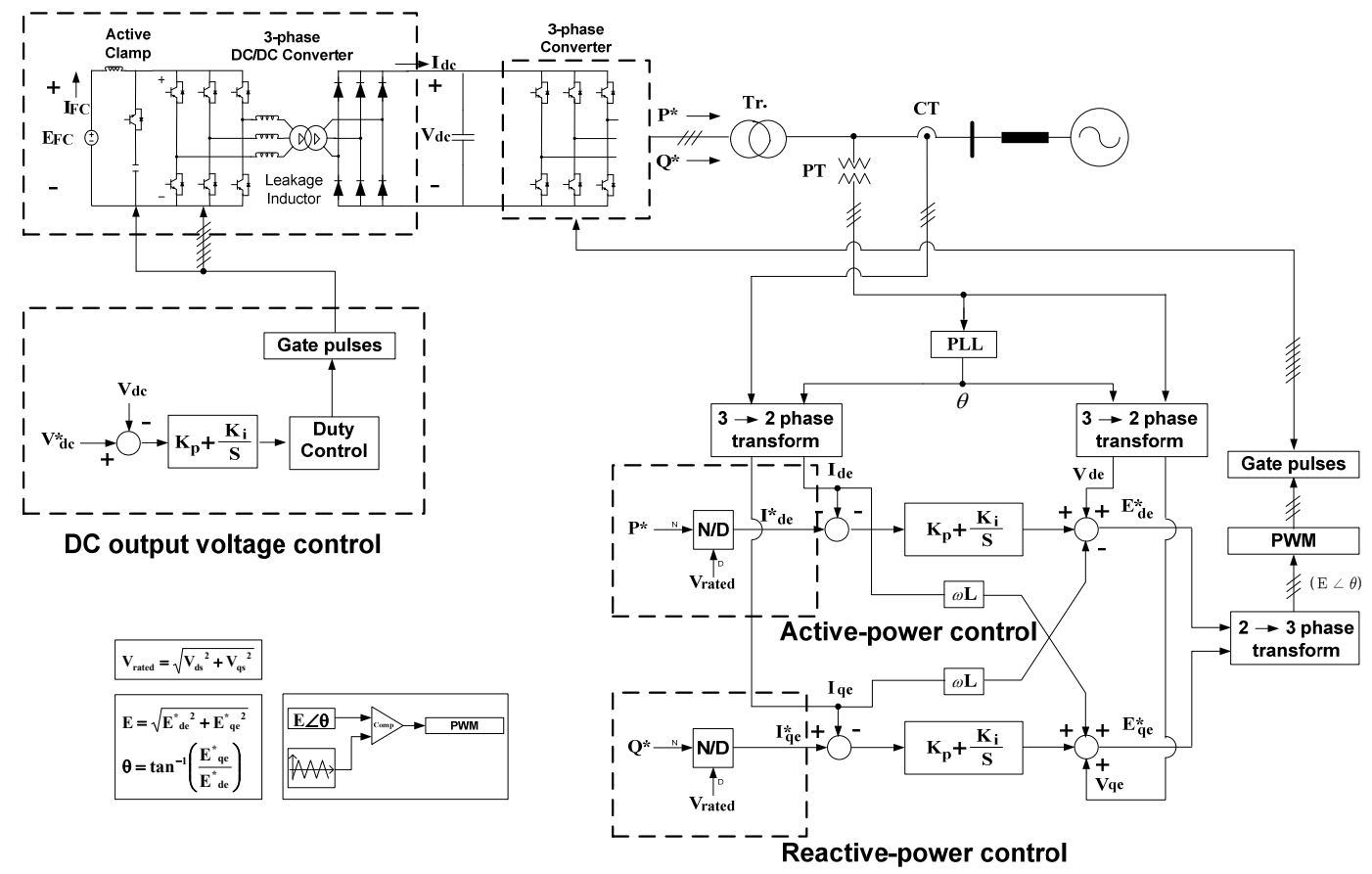

Fig. 1. Proposed power conditioning system for fuel cell.

part for the DC-DC converter and for the three-phase inverter. The control part for the DC-DC converter maintains the DC output voltage constant, while that for the inverter controls the active power $\mathrm{P}$ and the reactive power $\mathrm{Q}$ at the grid-tied point.

The control part for the DC-DC converter compares the measured DC capacitor voltage with the reference value and generates an error signal, which is then sent to the PI controller to determine the duty ratio. The three-phase DCDC converter maintains the output voltage at $400 \mathrm{~V}$ by generating six main switch gate signals with the duty ratio and the single active clamp switch gate signal with a complementary duty ratio. The control part for the inverter measures the three-phase voltage and current and performs the d-q transform with the phase-locked angle. It generates the reference values of the d-axis current and q-axis current, dividing the reference values of active power $\mathrm{P}$ and the reactive power $\mathrm{Q}$ by the rated voltage. These $\mathrm{d}$ and $\mathrm{q}$ reference currents are sent to the current control for generating the $\mathrm{d}$ and $\mathrm{q}$ reference voltage of the inverter. Meanwhile, the $\mathrm{d}$ and $\mathrm{q}$ reference voltage are used for generating the PWM pulses after performing inverse $\mathrm{d}-\mathrm{q}$ transform.

\section{Fuel Cell Modeling}

In the PEM fuel cell, the hydrogen gas is supplied to the anode through a platinum catalyst in order for it to be ionized into a hydrogen proton and an electron. The hydrogen proton moves to the cathode through the solid polymer membrane and is combined with the oxygen supplied to the cathode. Through this electron chemical reaction, the fuel cell generates electricity and heat, as well as water as a byproduct.

The ideal fuel cell voltage is the same as the equilibrium voltage represented by the Nernst model, which is based on Gip's free energy. The actual fuel cell voltage is represented by the reduction characteristic of the equilibrium voltage due to the polarization phenomenon.

The unit cell voltage of the fuel cell is represented by subtracting three polarization losses from the equilibrium voltage with respect to the exchange current density. The unit cell voltage shows non-linear characteristic and is expressed by eq. (1).

$$
E_{\text {cell }}=E_{\text {rev }}-E_{\text {act }}-E_{\text {con }}-E_{\text {ohm }}
$$

Where $E_{\text {rev }}$ is the equilibrium voltage; $E_{\text {act }}$ is the activated polarization loss; Econ is the concentration polarization loss; and $E_{\text {ohm }}$ is the ohmic polarization loss.

The activated polarization loss, which is due to the difference of the reaction speed on the electrode, is represented by eq. (2).

Where $i_{o}$ is the exchange current density related to the normal and reverse reactions between the electrolyte and the electrode.

The exchange current is dependent on the pressure, catalyst, activated energy, and temperature. If this value is reduced, the activated polarization $E_{a c t}$ is reduced and the output voltage of fuel cell $E_{\text {cell }}$ is increased. Hence, the exchange current is a very important parameter in fuel cell.

The concentration polarization loss Econ is due to the gradient difference of the reaction material concentration, which is represented by eq. (4). The ohmic polarization loss $E_{\text {ohm }}$, which is composed of electrolyte resistance, 


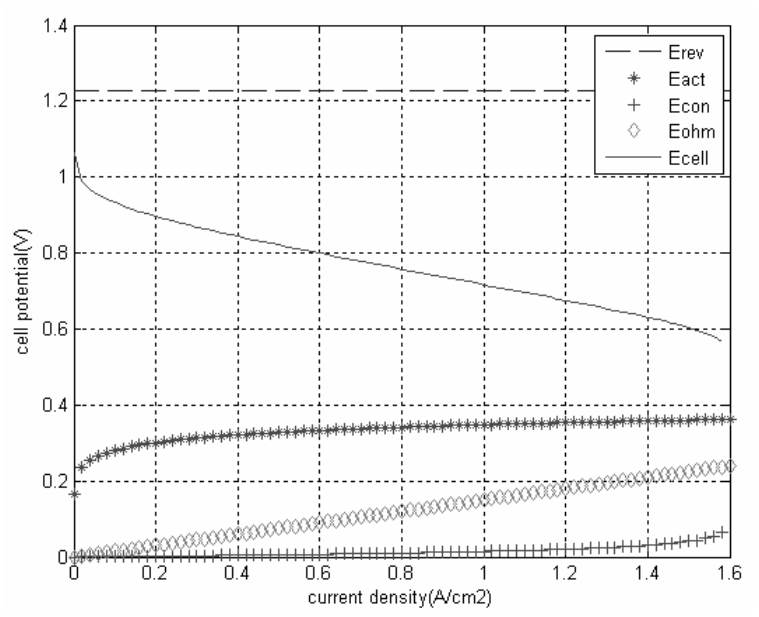

Fig. 2. Output voltage characteristic of fuel cell.

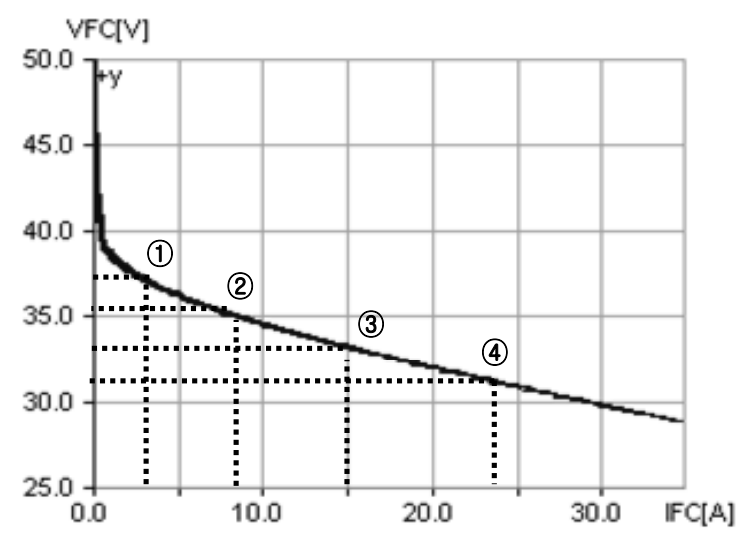

Fig. 3. Output characteristics modeling of fuel cell stack.

electrode resistance, and lead wire resistance, is represented by eq. (5).

$$
\begin{gathered}
E_{\text {act }}=\frac{R T}{\alpha F} \ln \left(\frac{i+i_{\text {loss }}}{i_{o}}\right) \\
i_{o}=i_{o}^{r e f} a_{c} L_{c}\left(\frac{P_{r}}{P_{r}^{r e f}}\right) \exp \left[-\frac{E_{c}}{R T}\left(1-\frac{T}{T_{r e f}}\right)\right] \\
E_{\text {con }}=\frac{R T}{n F} \ln \left(\frac{i_{L}}{i_{L}-i}\right) \\
E_{\text {ohm }}=i R_{i}
\end{gathered}
$$

Therefore, the output voltage characteristic of the fuel cell is represented by the five equations shown above. If all the parameters described in these equations are known for a specific fuel cell, its output voltage with respect to output current is easily analyzed.

Fig. 2 shows the output characteristic curves for a unit cell of a typical fuel cell. The actual cell output $E_{\text {cell }}$ is re-

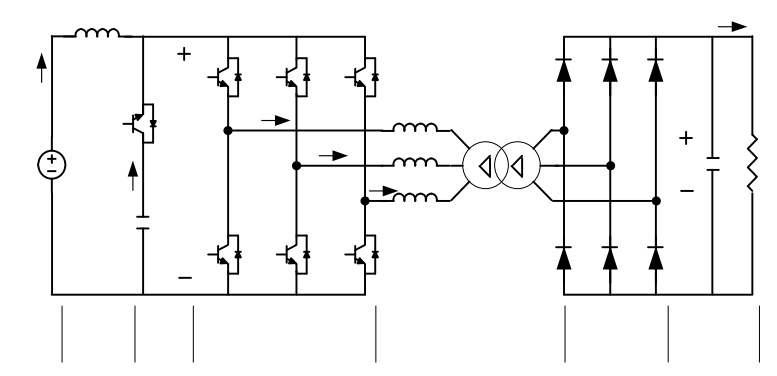

Fig. 4. Circuit diagram for three-phase DC-DC converter.

duced at a non-linear manner by three polarization components from the equilibrium voltage.

In actual fuel cells, many unit cells are connected in a series as a stack structure to build up the terminal voltage. Thus, the voltage and current characteristics of stack is determined by multiplying the unit cell voltage by the number of cells and multiplying the unit cell current density by the area of the cell.

Fig. 3 shows the output voltage characteristic of fuel cell stack that is composed of 47 cells. The y axis shows the actual output voltage, while the $\mathrm{x}$ axis shows the fuel cell current. This curve is required to design the DC-DC converter for fuel cell power conditioning system.

\section{Three-phase DC-DC Converter}

Fig. 4 shows the configuration of three-phase DC-DC converter with high boosting ratio and high efficiency, which is described in [9]. It consists of a three-phase current-fed converter whose outputs are connected to a threephase full-bridge diode rectifier through a delta-delta wound three-phase transformer. The three-phase currentfed converter is divided into a three-phase full-bridge converter configured as six main IGBT switches $\left(S_{1}-S_{6}\right)$ for three-phase DC/AC conversion, one auxiliary IGBT switch $\left(S_{C}\right)$ and clamp capacitor $C_{C}$ for the active clamp, and a DC boost inductor $L_{d c}$ acting as a current source. The main switches and auxiliary clamp switch perform ZVS through the use of resonance between leakage inductances of the three-phase transformer, clamp capacitor, output capacitances at IGBT switches, and stray capacitances in the transformer. Therefore, it reduces switching losses and leads to a highly efficient, isolated voltage boost converter. The advantages of employing a current-fed type with an active clamp in the DC/AC stage are as follows: the voltage across the switches is well clamped (i.e., no voltage overshoot); all switches operate with ZVS; no ancillary snubber is required in either the primary or secondary sides; the requirements for the output rectifier's speed are less stringent due to zero-current switching; and the input current generated from the fuel cells or photovoltaic source is continuous, with small ripples.

The sequence of topological states is shown in Fig. 5 and is described below. 


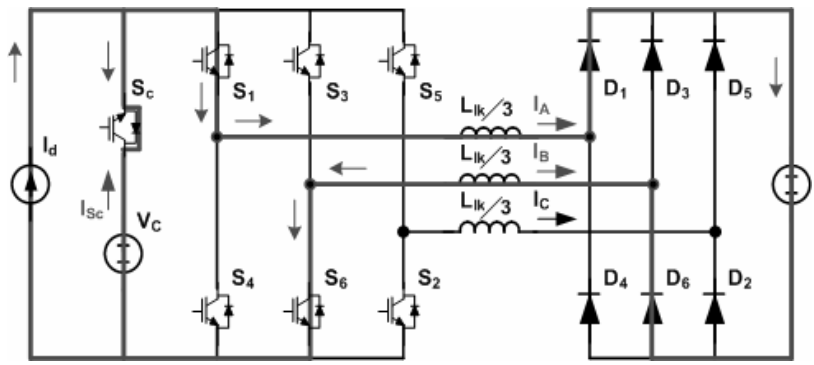

(a) Mode 1

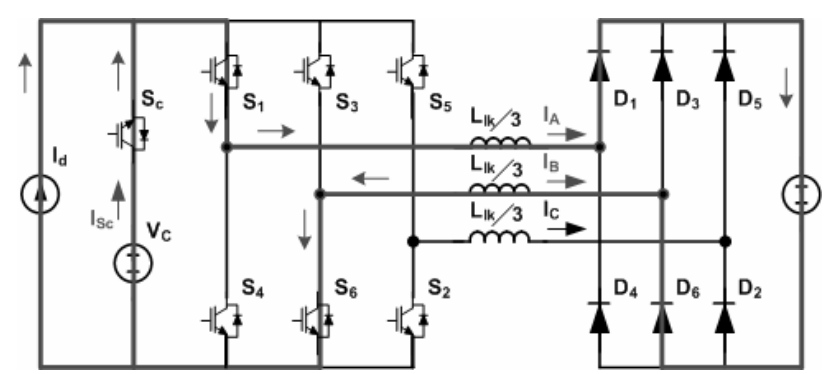

(b) Mode 2

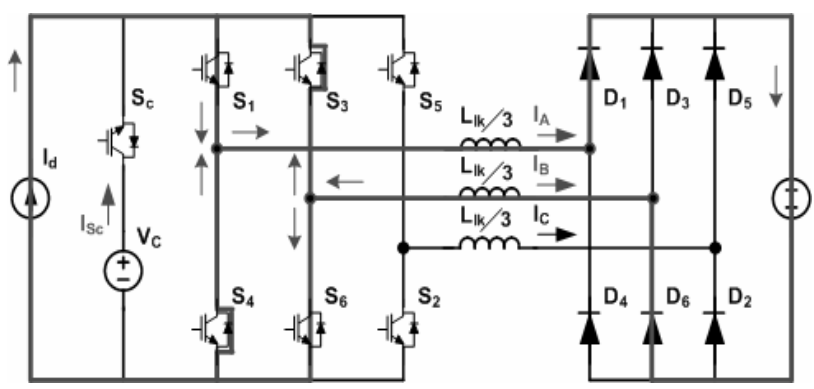

(c) Mode 3

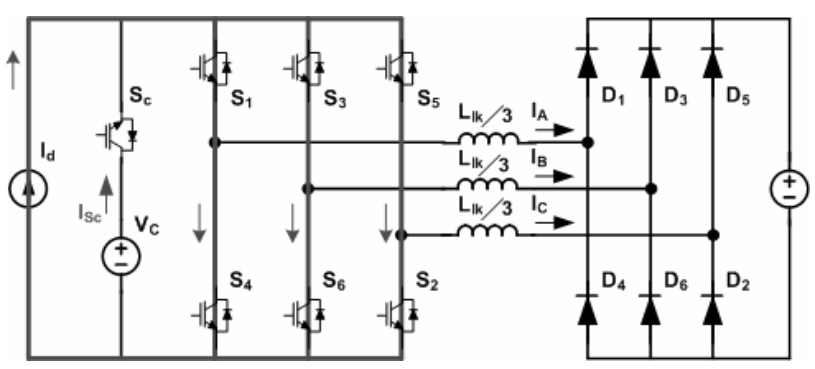

(d) Mode 4

Fig. 5. Operating modes of DC-DC converter.

\subsection{Operation Model $\left(t_{0}-t_{1}\right)$}

At $t_{0}$, the four switches $S_{2}-S_{5}$ are turned off, and $I_{S c}$ is $-I_{d}$. The bridge voltage $V_{P N}$ reaches and is clamped on the clamp capacitor voltage $V_{C}$. The current, through the leakage inductance $L_{l k}$, increases as a slope determined by the voltage difference between the clamp voltage $V_{C}$ and the reflected output voltage $V_{O}$.

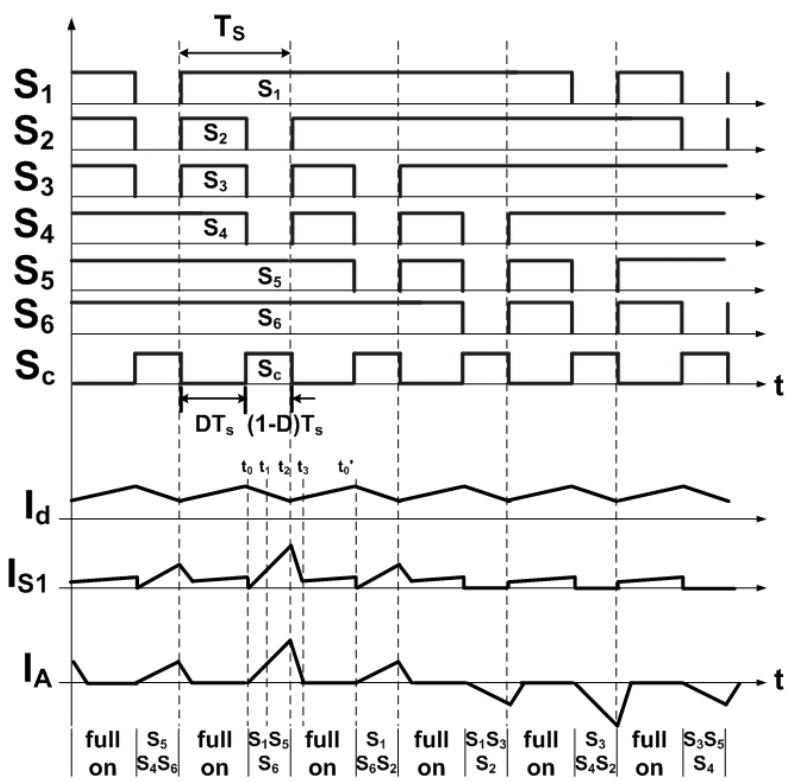

Fig. 6. Three-phase PWM generation.

\subsection{Operation Model $\left(t_{1}-t_{2}\right)$}

The clamp current $I_{S c}$ reverses its polarity and flows through MOSFET $S_{C}$. $I_{S c}$ provides the difference between the increasing $I_{A}$ and the constant boost inductor current $I_{d}$. $I_{S c}$ increases to $I_{d}$, and $I_{A}$ becomes two $I_{d}$ at $t_{2}$.

\subsection{Operation Model $\left(t_{2}-t_{3}\right)$}

At $t_{2}$, the active clamp switch $S_{C}$ is turned off and the energy stored in $L_{l k}$ discharges the output capacitances of $S_{3}$ and $S_{4}$. Then, $V_{P N}$ decreases to zero voltage and the body diodes of $S_{3}$ and $S_{4}$ begin to conduct. Therefore, all main switches including $S_{3}$ and $S_{4}$ can be turned on under a zerovoltage condition.

\subsection{Operation Model $\left(t_{3}-t_{4}\right)$}

At $t_{3}, I_{A}$ decreases to zero. All switches, $S_{1}-S_{6}$, are on and the boost inductor $L_{d c}$ charges energy. The same PWM scheme sequence in Fig. 5 is repeated.

Fig. 6 shows the ideal current waveforms of phase $A$ current $I_{A}$ and clamp current $I_{S c}$; the gating signals for the main switches $S_{I}-S_{6}$ clamp the switch $S_{C}$ together with the corresponding working switch pairs. Duty ratio $D$ is defined as an interval when all main switches are turned on and boost inductor $L_{d c}$ charges energy from input source $V_{d}$.

\section{Computer Simulation}

The operation of the proposed fuel cell power conditioning system was analyzed with the fuel cell model represented by the mathematical model described in [1]. The fuel cell current is determined by multiplying the cell cur- 
Table 1. Operation scenario for computer simulation

\begin{tabular}{c|c|c|c|c|c|c|c}
\hline Time $[\mathrm{s}]$ & $1^{(1)}$ & $2^{(2)}$ & $3^{(3)}$ & $4^{(4)}$ & 5 & 6 & 7 \\
\hline $\mathrm{P}[\mathrm{W}]$ & 100 & 300 & 500 & 700 & 500 & 300 & 100 \\
\hline $\mathrm{Q}[\mathrm{Var}]$ & 100 & 300 & 100 & 0 & 100 & 300 & 100 \\
\hline
\end{tabular}

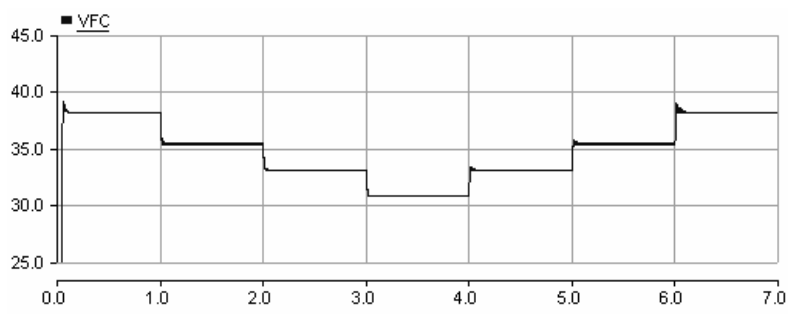

(a) Fuel cell operation voltage

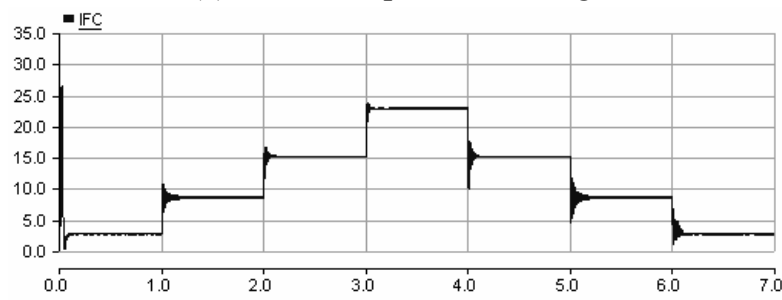

(b) Fuel cell operation current

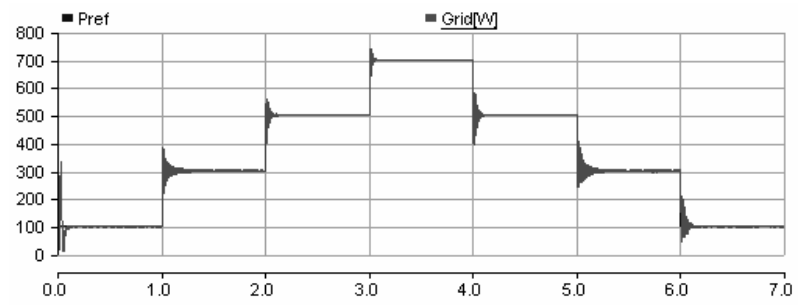

(c) Active power control

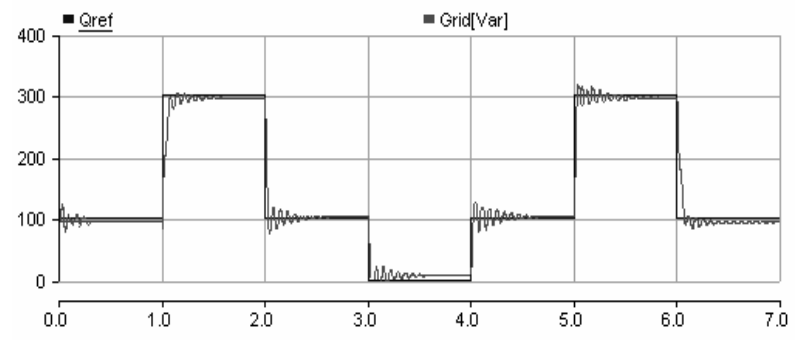

(d) Reactive power control

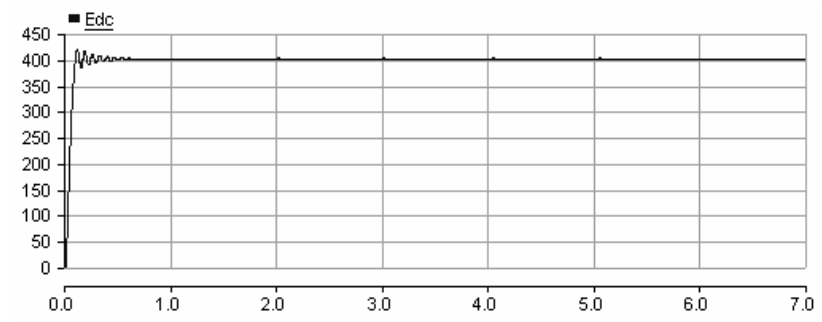

(e) DC output voltage control

Fig. 7. Simulation results of the proposed system.

rent density by the cell area. The fuel cell stack voltage is determined by multiplying the cell voltage by the number of stack. The simulation model consists of a fuel cell model, three-phase current-fed active clamp DC-DC converter, grid-tied inverter, and digital controller. The fuel cell model and the digital controller were represented by the userdefined models programmed with C-codes, while the three -phase current-fed active clamp DC-DC converter, gridtied inverter, and the three-phase voltage source were represented by built-in models in the PSCAD/EMTDC software.

In order to confirm the voltage and current variations of fuel cell according to the variation of active power, a simulation scenario was selected, as shown in Table 1. The active power varies with the step manner from 100 to $700 \mathrm{~W}$, and then down to $100 \mathrm{~W}$, while the reactive power varies from 0 to 300 Var, and then down to 0 Var during zero to seven seconds.

Fig. 7 shows the simulation results to verify the operation of the proposed system. The operation point at each output power is shown in Fig. 3. Fig. 7(a) shows the operation voltage of fuel cell, which changes according to the variation of the active power delivered to the grid.

Fig. 7(b) shows the operation current of fuel cell, which changes according to the variation of active power delivered to the grid similar to the case of the voltage variation.

Fig. 7(c) shows the tracking performance of active power, wherein the transient phenomena can be stabilized within one second and the steady-state tracking performance seems to be accurate. Fig. 7(d) shows the tracking performance of the reactive power, wherein the measured value of the reactive power tracks the reference value accurately and the transient phenomena is not so severe. Fig. 7(e) shows the tracking performance of the DC output voltage, which was maintained at $400 \mathrm{~V}$ without significant transients.

Fig. 7(c) shows the tracking performance of the active power, wherein the transient phenomena can be stabilized within one second and the steady-state tracking performance seems to be accurate. Fig. 7(d) shows the tracking performance of the reactive power, wherein the measured value of the reactive power tracks the reference value accurately and the transient phenomena is not so severe. Fig. 7(e) shows the tracking performance of the DC output voltage, which was maintained at $400 \mathrm{~V}$ without significant transients.

\section{Experimental Works}

Based on the simulation results, a prototype of the proposed system was built and tested to confirm the feasibility of hardware implementation. The fuel cell power generation unit used in the experiment is the $1.2 \mathrm{~kW}$ Ballard Nexa PEM Module. The controller for the three-phase DC-DC converter adjusts the duty ratio of the converter to maintain the output voltage. The voltage boosting is carried out by the duty ratio of the current-fed converter and the winding ratio of the high-frequency transformer. The three-phase DC-DC converter was designed with $10 \mathrm{kHz}$ of switching frequency and generates three-phase PWM patterns by 
Table 2. Operation scenario for the hardware experiment

\begin{tabular}{c|c|c|c|c|c|c|c|c|c|c}
\hline Time $[\mathrm{s}]$ & 50 & 100 & 150 & 200 & 250 & 300 & 350 & 400 & 450 & 500 \\
\hline $\mathrm{P}[\mathrm{W}]$ & 100 & 100 & 300 & 500 & 700 & 700 & 500 & 300 & 100 & 100 \\
\hline $\mathrm{Q}[\mathrm{Var}]$ & 0 & 100 & 300 & 100 & 0 & 0 & 100 & 300 & 100 & 100 \\
\hline
\end{tabular}

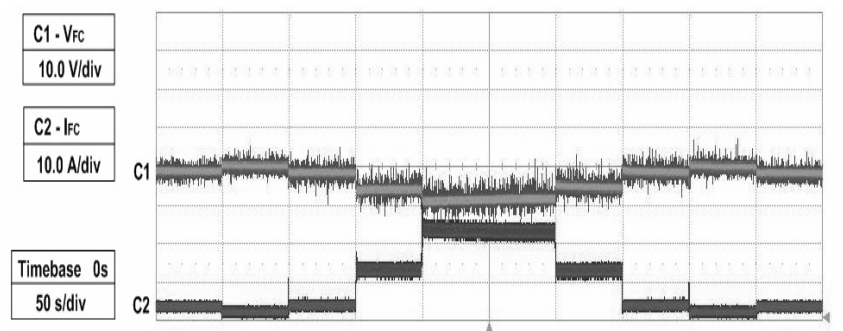

(a) Fuel cell operation voltage and current

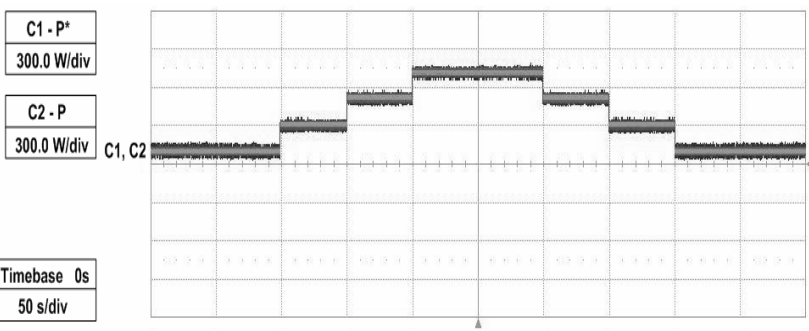

(b) Active power Control

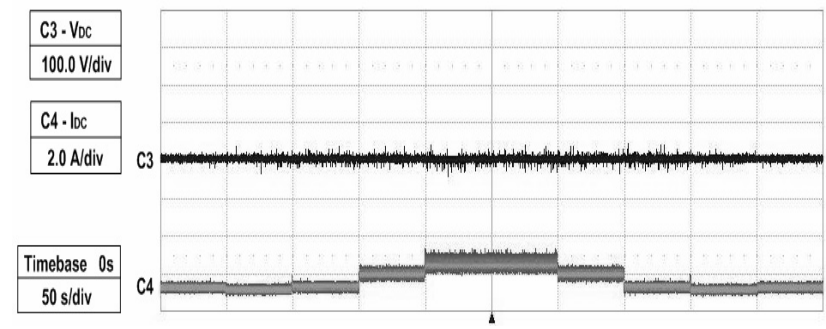

(c) DC output voltage and current

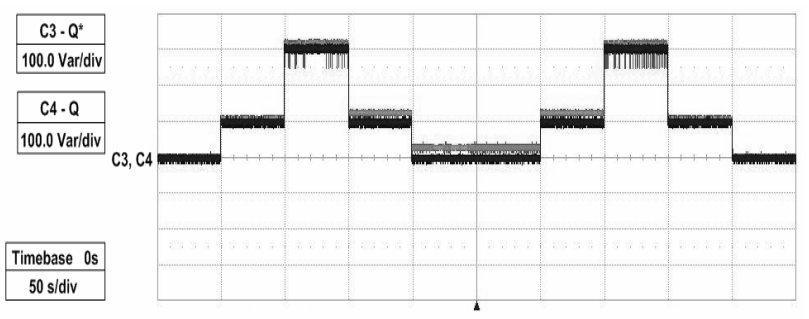

(d) Reactive power Control

Fig. 8. Experimental results of hardware prototype.

using field programmable gate array.

The controller was designed and built with a floatingpoint digital signal processor (DSP), TMS320vc33-150 by $\mathrm{TI}$, and erasable programmable logic device (EPLD), EP1K100QC208 by Altera. The control board has 24 channels of ADC, 4 channels of DAC, 4 channels of digital input, 4 channels of digital output, 1 module of encoder pulse input, 1 port of RS232, and 2 ports of RS485. The actual fuel cell stack cannot track the fast variation of the active power in the grid because the chemical reaction in the fuel

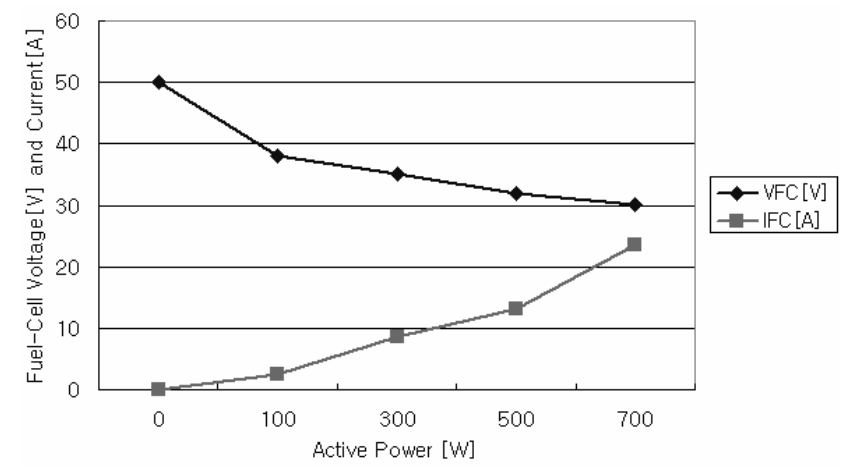

Fig. 9. Measured fuel cell voltage and current.

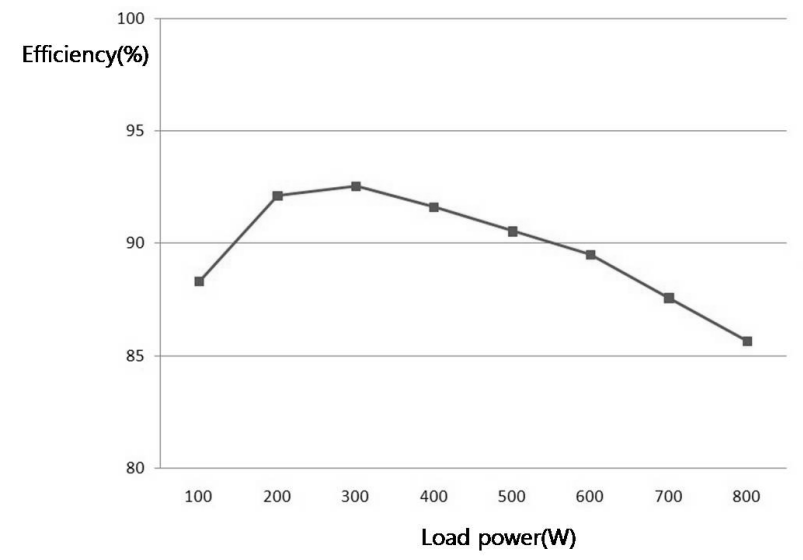

Fig. 10. Measured efficiency of converter.

cell stack is relatively much slower. In order to confirm a safe and reliable operation, the duration of the active power variation was determined to be 100 seconds in the experimental work.

Fig. 8 shows the experimental results for verifying the operation of the proposed system. Fig. 8(a) shows the operation voltage and current of fuel cell module with 10 $\mathrm{V}(\mathrm{A}) /$ div. The time div was selected as 100 seconds, which is the same as the duration period of the active or reactive power. As the active power increases, the fuel cell voltage decreases while the fuel cell current increases. Fig. 8(b) shows that the measured active power tracks the reference value accurately without severe transient. Fig. 8(c) shows the output voltage and the current variation of fuel cell. The output current has the same variations as the active power when the capacitor voltage is maintained at $400 \mathrm{~V}$. This confirms that the DC-DC converter can accurately control the output voltage without the variation of active power. Fig. 8(d) shows that the measured reactive power tracks the reference value accurately without severe transient.

Fig. 9 shows the voltage-current characteristic curve of the fuel cell module used in the experiment. The no-load voltage of the fuel cell is about $50 \mathrm{~V}$; the terminal voltage decreases while the output current increases as the active power increases. At the active power of $700 \mathrm{~W}$, the fuel cell voltage is $30.02 \mathrm{~V}$ and current is $23.56 \mathrm{~A}$. 
Fig. 10 shows the efficiency of the three-phase DC-DC converter, which was measured through experimental works. As active power increases, fuel cell current also increases, thus conduction losses in the DC-DC converter increase by a square and efficiency drops significantly. The efficiency can be improved by sizing magnetic components suitable for $1 \mathrm{~kW}$ power level.

\section{Conclusion}

This paper described the performance analysis results of the grid-tied power conditioning system for fuel cells, which is composed of three-phase DC-DC converter and three-phase PWM inverter.

The three-phase DC-DC converter boosts fuel cell voltage of $26-48 \mathrm{~V}$ up to $400 \mathrm{~V}$ using the ZVS switching scheme, while the three-phase PWM controls the active and reactive power independently.

The feasibility of the hardware implementation was verified through experimental works with a laboratory prototype, which was built with $1.2 \mathrm{~kW}$ PEM fuel cell stack. The proposed power conditioning system can be commercialized to interconnect the fuel cell with the power grid.

\section{Acknowledgments}

This research was financially supported by the 2010 research fund of Myongji University and the advanced human resource development program of MKE through the Research Center for Intelligent Microgrid.

\section{References}

[1] Gregor Hoogers, "FUEL CELL TECHNOLOGY HANDBOOK", CRC Press, 2003.

[2] Bouneb, B., Grant, D.M., Cruden, A., McDonald, J.R., "Grid connected inverter suitable for economic residential fuel cell operation", Power Electronics and Applications, 2005 European Conference on 0-0 0 Page(s): 10 pp.-P.10

[3] Mousavi, A.; Das, P.; Moschopoulos, G, "A ZCSPWM Full-Bridge Boost Converter for Fuel-Cell Applications", Applied Power Electronics Conference and Exposition, 2009. APEC 2009. Twenty-Fourth Annual IEEE 15-19 Feb. 2009 Page(s):459-464.

[4] Mousavi, A.; Das, P.; Moschopoulos, G, "A ZCSPWM Full-Bridge Boost Converter for Fuel-Cell Applications", Applied Power Electronics Conference and Exposition, 2009. APEC 2009. Twenty-Fourth Annual IEEE 15-19 Feb. 2009 Page(s):459-464.

[5] Wingelaar, P.J.H. Duarte, J.L. Hendrix, M.A.M "Dynamic Characteristics of PEM Fuel Cells", IEEE Power Electronics Specialists Conference 2005, 16-
20 June 2005, Page(s):1635-1641.

[6] Wang, C.; Nehrir, M.H., "Distributed Generation Applications of Fuel Cells", Power Systems Conference: Advanced Metering, Protection, Control, Communication, and Distributed Resources, 2006. PS '06 1417 March 2006 Page(s):244-248

[7] Rathore, A.K, Bhat, A.K.S. Oruganti, R, "A Comparison of Soft-Switched DC-DC Converters for Fuel Cell to Utility Interface Application", Power Conversion Conference-Nagoya, 2007. PCC '07 2-5 April 2007 Page(s):588-594.

[8] Lin, B.-R.; Hsieh, F.-Y.; Wang, D.; Huang, K., "Analysis, design and implementation of active clamp zero voltage switching converter with output ripple current cancellation", Electric Power Applications, IEE Proceedings -Volume 153, Issue 5, September 2006 Page(s):653-663.

[9] Hanju Cha, Jungwan Choi, and Prasad N. Enjeti, "A Three-Phase Current-Fed DC/DC Converter With Active Clamp for Low-DC Renewable Energy Sources", IEEE Trans. On Power Electronics, Vol.23, No.6, November 2008.

[10] Yu, X.; Starke, M.R.; Tolbert, L.M.; Ozpineci, B., "Fuel cell power conditioning for electric power applications: a summary", Electric Power Applications, IET Volume 1, Issue 5, Sept. 2007 Page(s):643-656.

[11] Sung-Yeul Park; Chien-Liang Chen; Jih-Sheng Lai, "Wide range active and reactive power flow controller for a solid oxide fuel cell power conditioning system", Applied Power Electronics Conference and Exposition, 2008. APEC 2008. Twenty-Third Annual IEEE 24-28 Feb. 2008 Page(s):952-958.

[12] Jung-Min Kwon; Eung-Ho Kim; Bong-Hwan Kwon; Kwang-Hee Nam, "High-Efficiency Fuel Cell Power Conditioning System With Input Current Ripple Reduction", Industrial Electronics, IEEE Transactions on Volume 56, Issue 3, March 2009 Page(s):826-834.

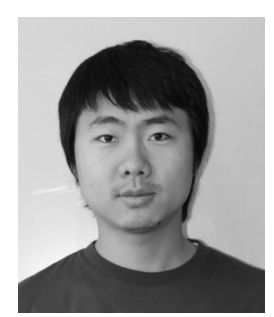

Jong-Kyou Jeong received his B.S. and M.S. degrees in Electrical Engineering from Myongji University, Korea in 2008 and 2010, respectively. $\mathrm{He}$ is currently working toward his Ph.D. at Myongji University. His research interests are in power electronics applications for custom power and distributed generation.

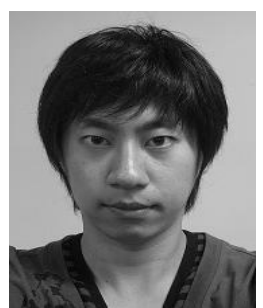

Ji-Heon Lee received his B.S. degree in Electrical Engineering from Myongji University, Korea in 2008. He is currently a Masteral student at Myongji University. His research interests are in power electronics applications for custom power and distributed generation. 


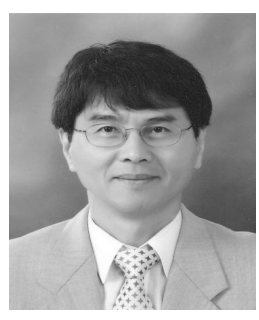

Byung-Moon Han received his B.S. degree in Electrical Engineering from Seoul National University, Korea in 1976 and his M.S. and Ph.D. degrees from Arizona State University in 1988 and 1992, respectively. He was with the Westinghouse Electric Corporation as a Senior Research Engineer in the Science and Technology Center. Currently, he is a Professor in the Department of Electrical Engineering at Myongji University, Korea. His research interests are in power electronics applications for FACTS, custom power, and distributed generation.

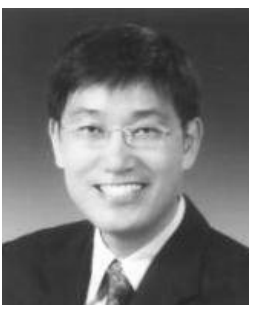

Hanju Cha received his B.S. degree in Electrical Engineering from Seoul National University, Seoul, Korea; his M.S. degree from Pohang Institute of Science and Technology, Korea; and his Ph.D. degree from Texas A\&M University, College Station in 1988, 1990, and 2004, respectively. From 1990 to 2001, he was with LG industrial system, Anyang, Korea, where he was engaged in the development of power electronics and adjustable speed drives.

In 2005, he joined the Department of Electrical Engineering, Chungnam National University, Daejeon, Korea. His current research interests are high-power converter, $\mathrm{AC} / \mathrm{DC}$, $\mathrm{DC} / \mathrm{AC}$, and $\mathrm{AC} / \mathrm{AC}$ converter topologies, power quality, and utility interface issues for distributed energy system and microgrids. 